\title{
Bi-allelic loss of function variants in SLC30A5 as cause of perinatal lethal cardiomyopathy
}

\author{
Johann Kaspar Lieberwirth $\mathbb{1}^{1}$ - Pascal Joset ${ }^{2} \cdot$ Anja Heinze $^{1} \cdot$ Julia Hentschel $^{1}$ - Anja Stein ${ }^{3}$ • \\ Antonella lannaccone $^{4} \cdot$ Katharina Steindl $^{2} \cdot$ Alma Kuechler $^{5} \cdot$ Rami Abou Jamra $^{1}{ }^{1}$
}

Received: 30 September 2020 / Revised: 13 December 2020 / Accepted: 17 December 2020 / Published online: 5 February 2021

(c) The Author(s) 2021. This article is published with open access

\begin{abstract}
Perinatal mortality is a heavy burden for both affected parents and physicians. However, the underlying genetic causes have not been sufficiently investigated and most cases remain without diagnosis. This impedes appropriate counseling or therapy. We describe four affected children of two unrelated families with cardiomyopathy, hydrops fetalis, or cystic hygroma that all deceased perinatally. In the four patients, we found the following homozygous loss of function (LoF) variants in SLC30A5 NM_022902.4:c.832_836del p.(Ile278Phefs*33) and NM_022902.4:c.1981_1982del p.(His661Tyrfs*10). Knockout of SLC30A5 has previously been shown a cardiac phenotype in mouse models and no homozygous LoF variants in SLC30A5 are currently described in gnomAD. Taken together, we present $S L C 30 A 5$ as a new gene for a severe and perinatally lethal form of cardiomyopathy.
\end{abstract}

\section{Introduction}

Stillbirth occurs in developed countries with a frequency of 3-4 per 1000 pregnancies [1-3]. The possible causes of stillbirths are very heterogeneous and include, but are not limited to infections, maternal risk factors (e.g., diabetes,

These authors contributed equally: Alma Kuechler, Rami Abou Jamra

Alma Kuechler

alma.kuechler@uni-due.de

$\triangle$ Rami Abou Jamra

rami.aboujamra@medizin.uni-leipzig.de

1 Institute of Human Genetics, University Medical Center Leipzig, Leipzig, Germany

2 Institute of Medical Genetics, University of Zurich, Schlieren, Switzerland

3 Department of Pediatrics I, Division of Neonatology, University Medical Center Essen, University Duisburg-Essen, Essen, Germany

4 Department of Gynecology and Obstetrics, University Medical Center Essen, University Duisburg_Essen, Essen, Germany

5 Institute of Human Genetics, University Medical Center Essen, University of Duisburg-Essen, Essen, Germany obesity, smoking), pregnancy complications such as placenta dysfunction, preeclampsia, or asphyxia, congenital fetal anomalies, and genetic conditions [4]. Especially for genetic causes, the underlying mechanisms have not yet been sufficiently understood. In developed countries, hydrops fetalis occurs in $~ 9 \%$ of all stillbirths [5] with a general frequency of around 1 out of 2500 pregnancies [6,7]. The majority (90\%) of cases of fetal hydrops in western countries have shown to be non-immunological (NIHF), while cardiovascular causes $(20 \%)$ represent the most frequent origin of this condition [6, 8]. Apart from chromosomal disorders and classical syndromes such as Noonan's syndrome, underlying causes of fetal hydrops are difficult to decipher. Still only half of these cases can be explained [9] and numerous underlying genes remain to be explored. Only with the advent of broadbased in-depth genetic analyses including exome sequencing (ES), an even greater variety of genetic causes for fetal anomalies can be detected [10, 11]. Identifying the precise etiology of NIHF is essential for effective clinical management of these pregnancies as well as for better counseling of families regarding prognosis, risk of recurrence, and prenatal diagnostics [6].

Here we describe four individuals from two unrelated families in which we identified homozygous loss of function (LoF) variants in the zinc transporter SLC30A5. Affected individuals shared a similar phenotype of cardiomyopathy and deceased perinatally. 


\section{Materials and methods}

\section{Family consolidation}

Families were consolidated via the online match making platform GeneMatcher [12].

\section{Exome sequencing}

ES was performed for seven of the eight available family members with the exception of the father of family 1 , who was subjected to targeted Sanger sequencing for verification of the detected variant. After library preparation (Nextera DNA Flex, Illumina), target-enrichment and paired-end sequencing was performed differently for families 1 and 2 . While the Human Core Exome, Twist Bioscience, and a NovaSeq 6000 Instrument (S1 Reagent Kit, 300 cycles, Illumina) were used for family 1 ; $x$ Gen $^{\oplus}$ Exome Research Panel v1.0, IDT, and a HiSeq instrument (SBS Kit v4, Illumina) were the methods used in case of family 2 . For all seven ES, coverage of more than 20x was achieved in more than $95 \%$ of target sequences.

\section{Variant prioritization}

For family 1, bioinformatic analysis was performed using the software Varfeed and Varvis (Limbus, Rostock, Germany). For family 2, bioinformatic analysis was performed using NextGENe (SoftGenetics, PA, USA). Mapping was carried out using hg19.

We evaluated all variants that are annotated in mutation databases (primarily HGMD and ClinVar [13, 14]) as well as rare (minor allele frequency below 1\%) potential proteininfluencing variants. We prioritized the variants based on minor allele frequency, inheritance mode, and potential predicted pathogenicity (based on a number of in silico predictions). Since no pathogenic or likely pathogenic variants could be identified in any known disease genes in either family, we continued evaluation of the sequencing data in a scientific setting on the basis of a previously written consent. Further variants in genes with no prior association to disorders have then been prioritized based on the mentioned parameters above as well as on attributes of the genes, like functional plausibility and gene constraints (i.e., LOEUF value and Z-score [15]). Additional aspects including availability of animal models, interaction partners, and plausibility of the symptoms were also considered in regard to the function of the gene.

\section{Results}

Detailed clinical data can be found in Table 1.
Clinical description

Family 1

All three pregnancies in family 1 were affected by complications with fetal hydrops and perinatal death. Postmortem examinations were performed on two of the three children and both were found to have cardiomyopathy. The healthy parents are first cousins.

The first pregnancy (Fig. 1, 1.1) was uneventful apart from gestational diabetes. Rhesus prophylaxis was carried out properly. Sonographic screenings at 11 and 20 weeks were inconspicuous. A checkup at $30^{+6}$ weeks of gestation showed a pathologic CTG and pathologic Doppler as well as a massive fetal hydrops (Fig. 2A). An emergency cesarean section was carried out immediately and the girl was born with $37 \mathrm{~cm}$ length (13 percentile, $Z=-1.12$ [16]), $1720 \mathrm{~g}$ weight (71 percentile, $Z=0.55$ ), and $32 \mathrm{~cm}$ head circumference (95 percentile, $Z=1.61$ ); APGAR 01/01/01, umbilical cord pH 7.16. Despite extensive resuscitation efforts, the infant girl remained bradycardic and deceased. Microarray analysis and gene panel sequencing were inconspicuous.

In the second pregnancy (Fig. 1, 1.2), a right ventricular hypertrophy and a cardiomegaly were diagnosed by ultrasonic imaging in the 22nd gestational week, but the amount of amniotic fluid remained normal at this time. As a consequence of a commencing hydrops fetalis that was observed in the 28th gestational week, an attempt was made to save the child by a cesarean section at $27^{+5}$ weeks (APGAR 03/04/04, umbilical cord $\mathrm{pH}$ 7.34). Birth measurements were normal for gestational age (length of $36.5 \mathrm{~cm}$ (46 percentile, $Z=-0.11$ ), weight of $1120 \mathrm{~g}$ (55 percentile, $Z=0.12$ ), and head circumference of $28 \mathrm{~cm}$ (80 percentile, $Z=0.85)$ ). ECG showed ventricular bradycardia with wide chamber complexes with 2 to 1 conduction of the normal atrial frequency, arrhythmia was refractory to therapy. Echocardiography suggested a noncompaction cardiomyopathy (Fig. 2E).

Brain sonography on the 1 st day of life revealed an immature gyration and frontal hygroma (Fig. 2C). At age 2 days, pronounced thalamic and intraventricular hemorrhage was observed. Diagnostic tests did not show any evidence of metabolic disease or infections.

Despite intensive care, the boy died after 4 days. Postmortem examination did not show evidence of congenital malformations. Histological examination of cardiac tissue revealed the suspected cardiomyopathy of the noncompaction type. Furthermore, an immature placenta and a normal fetogram on X-ray were found.

Subsequent ES of the mother, child 1.1 and child $1.2 \mathrm{did}$ not reveal robust variants that could explain the phenotype in question.

The third pregnancy (Fig. 1, 1.3) showed a similar course. Polyhydramnios, mild myocardial hypertrophy, and small 
Table 1 Detailed clinical information on individuals.

\begin{tabular}{|c|c|c|c|c|}
\hline Patient index & 1.1 & 1.2 & 1.3 & 2.1 \\
\hline \multicolumn{5}{|l|}{ Genetic data } \\
\hline $\begin{array}{l}\text { SLC30A5 variant (GRCh37; } \\
\text { NM_022902.4) }\end{array}$ & \multicolumn{3}{|c|}{ c.832_836del p.(Ile278Phefs*33) chr5:g.68411799_68411803del } & $\begin{array}{l}\text { c.1981_1982del p.(His661Tyrfs*10) } \\
\text { chr5:g.68419235_68419236del }\end{array}$ \\
\hline Zygosity & \multicolumn{3}{|l|}{ Homozygous } & Homozygous \\
\hline \multicolumn{5}{|l|}{ General } \\
\hline Consanguinity & \multicolumn{3}{|l|}{ Yes } & Yes \\
\hline Sex & Female & Male & Female & Male \\
\hline Other genetic investigations & $\begin{array}{l}\text { Karyotyping: } 46, \mathrm{XX} \text {; gene panel } \\
\text { sequencing }\end{array}$ & Karyotyping: 46,XY & Karyotyping: 46,XX & $\begin{array}{l}\text { Array analysis unobtrusive, } \\
\text { Karyotyping: } 46, X Y\end{array}$ \\
\hline Age at last assessment & $30^{+6}$ & $27^{+5}$ & $31^{+3} / 32^{+0}$ (p.m.) & 1st day of life \\
\hline \multicolumn{5}{|l|}{ Pregnancy } \\
\hline Gravidity and parity & G1P1 & $\mathrm{G} 2 \mathrm{P} 2$ & G3P3 & $\mathrm{G} 2 \mathrm{P} 2$ \\
\hline Gestational parameters & $\begin{array}{l}\text { Spontaneously occurring pregnancy, } \\
\text { normal sonographic screenings at } 11 \\
\text { and } 20 \text { weeks, gestational diabetes, } \mathrm{Rh} \\
\text { prophylaxis }\end{array}$ & $\begin{array}{l}\text { Spontaneously occurring } \\
\text { pregnancy, first } \\
\text { sonographic screenings } \\
\text { normal, Rh prophylaxis }\end{array}$ & $\begin{array}{l}\text { Spontaneously } \\
\text { occurring pregnancy, } \\
\text { first sonographic } \\
\text { screenings normal, } \\
\text { Rh prophylaxis }\end{array}$ & $\begin{array}{l}\text { Spontaneously occurring; no } \\
\text { abnormalities until } 31 \text { st week of } \\
\text { gestation }\end{array}$ \\
\hline $\begin{array}{l}\text { Prenatal complications/birth } \\
\text { history? }\end{array}$ & Generalized hydrops fetalis & $\begin{array}{l}22 \text { nd week of gestation: } \\
\text { right ventricular } \\
\text { hypertrophy, } \\
\text { cardiomegaly, later on } \\
\text { beginning hydrops } \\
\text { fetalis }\end{array}$ & $\begin{array}{l}29^{+5} \text { weeks of } \\
\text { gestation: } \\
\text { polyhydramnios, } \\
\text { release punctures, } \\
\text { hydrops fetalis, } \\
\text { intrauterine fetal } \\
\text { death, } \\
\text { cardiomyopathy }\end{array}$ & $\begin{array}{l}\text { 31st week of gestation: } \\
\text { polyhydramnios; } 33 \text { rd week: } \\
\text { hypertrophic right ventricle, congenital } \\
\text { limb contractures }\end{array}$ \\
\hline Decease & 25 min after birth & 4th day of life & $\begin{array}{l}\text { IUFD after } 31 \\
\text { gestational weeks }\end{array}$ & 5th day of life \\
\hline Birth mode & $\begin{array}{l}\text { Emergency C-section due to pathologic } \\
\text { CTG }\end{array}$ & C-section & Spontaneous & C-section \\
\hline APGAR, umbel. Cord $\mathrm{pH}$ & $01 / 01 / 01,7.16$ & $03 / 04 / 04,7.34$ & n.a. (IUFD) & APGAR: 01/05/07 \\
\hline Amniotic fluid & Polyhydramnios, TORCH normal & Normal & Polyhydramnios & n.a. \\
\hline \multicolumn{5}{|l|}{ Auxological data at birth } \\
\hline Birth weight (SD) & $1720 \mathrm{~g}(0.55)$ & $1120 \mathrm{~g}(0.12)$ & $1185 \mathrm{~g}(-1.54)$ & $2770 \mathrm{~g}(-0.82)$ \\
\hline Birth length (SD) & $37 \mathrm{~cm}(-1.12)$ & $36.5 \mathrm{~cm}(-0.11)$ & $40 \mathrm{~cm}(-0.79)$ & n.a. \\
\hline Birth OFC (SD) & $32 \mathrm{~cm}(1.61)$ & $28 \mathrm{~cm}(0.85)$ & $29 \mathrm{~cm}(-1.69)$ & n.a. \\
\hline \multicolumn{5}{|l|}{ Postmortem investigation } \\
\hline Clinical & $\begin{array}{l}\text { Massive hydrops fetalis, hypertrophic } \\
\text { placenta, three umbilical cord vessels }\end{array}$ & $\begin{array}{l}\text { Hydrops fetalis, } \\
\text { immature placenta, three } \\
\text { umbilical cord vessels }\end{array}$ & $\begin{array}{l}\text { Hydrops fetalis, } \\
\text { immature placenta, } \\
\text { three umbilical cord } \\
\text { vessels }\end{array}$ & Cystic neck hygroma \\
\hline Autopsy & n.p. & $\begin{array}{l}\text { Histological verification } \\
\text { of non-compaction-type } \\
\text { cardiomyopathy }\end{array}$ & n.p. & $\begin{array}{l}\text { Neuropathological investigation: no } \\
\text { pathological findings }\end{array}$ \\
\hline X-ray & n.p. & Normal fetogram & n.p. & Small ribs \\
\hline \multicolumn{5}{|l|}{ Other features } \\
\hline Dysmorphic features & No & No & $\begin{array}{l}\text { Small deep-set ears, } \\
\text { flat facial profile }\end{array}$ & Mild dysmorphic features \\
\hline Genitourinary anomalies & n.a. & No & n.a. & Hypoplastic scrotum \\
\hline Cardiovascular anomalies & n.a. & $\begin{array}{l}\text { Non-compaction-type } \\
\text { cardiomyopathy, } \\
\text { ventricular bradycardia, } \\
\text { arrhythmia with } \\
\text { intermittent } 2: 1 \\
\text { conduction of normal } \\
\text { atrial frequency }\end{array}$ & Cardiomyopathy & $\begin{array}{l}\text { Right ventricular hypertrophy, } \\
\text { ventricular tachycardia, broad-complex } \\
\text { tachycardias, and bradycardia }\end{array}$ \\
\hline Neurological anomalies & n.a. & $\begin{array}{l}\text { Immature gyration, } \\
\text { frontal hygroma, } \\
\text { intraventricular, and } \\
\text { parenchymal } \\
\text { hemorrhage beginning } \\
\text { on 2nd day of life }\end{array}$ & No & No \\
\hline Skin anomalies & Skin edema & Skin edema & Skin edema & Dystrophic nails \\
\hline Family history & \multicolumn{3}{|c|}{ Apart from these 3 affected siblings family history negative for hydrops or CMP } & $\begin{array}{l}\text { Elder sister healthy, family history } \\
\text { uneventful }\end{array}$ \\
\hline
\end{tabular}



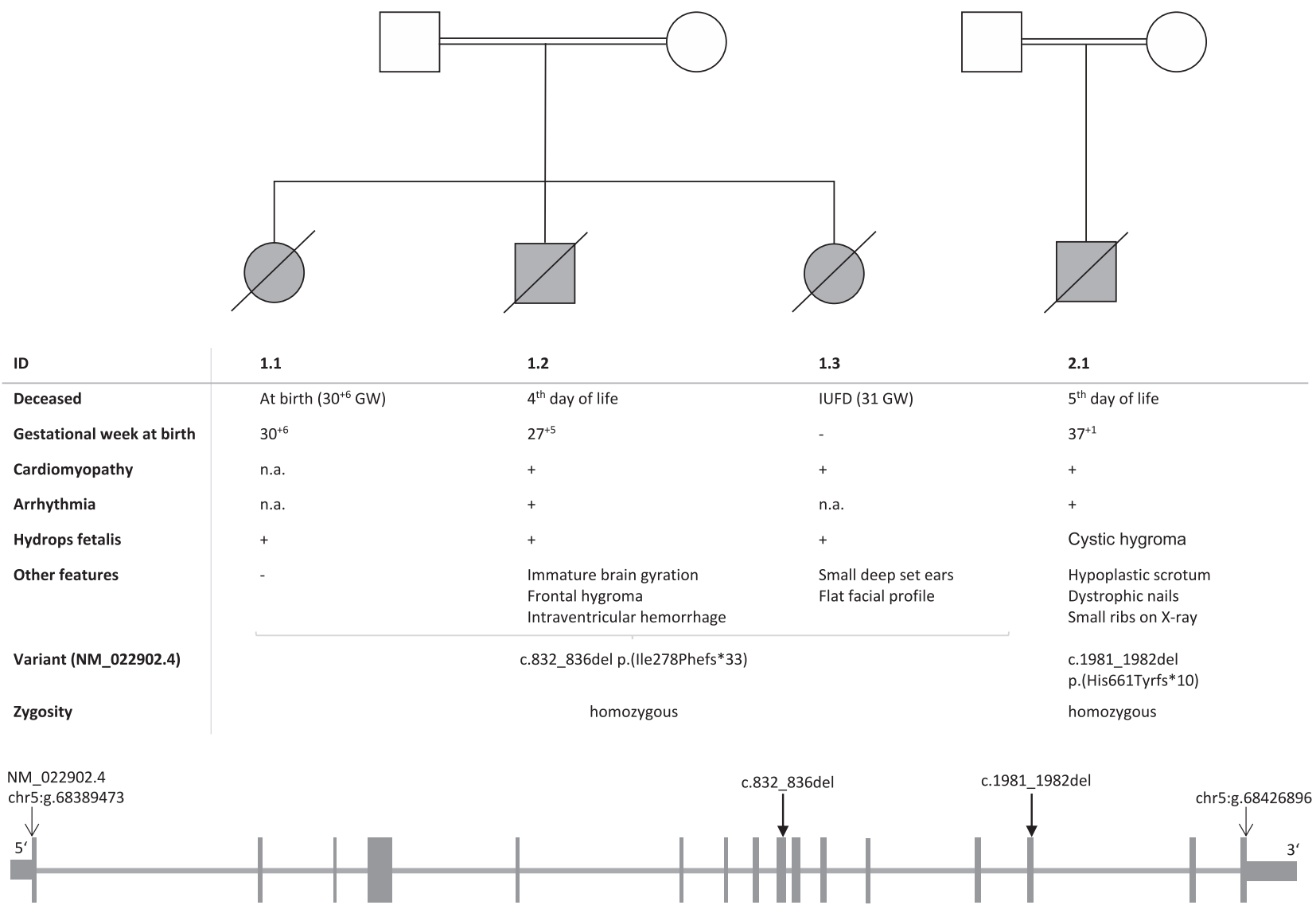

Fig. 1 Overview on individuals. The figure lists key information on all affected individuals including variant postions. The conventional symbols were used for the pedigrees.

ventricular septal defect were diagnosed in the 28th week of gestation; hydrops was seen a few days later (Fig. 2B-F). Amniotic fluid was punctured twice (at 29th and 30th gestational weeks) to relieve the polyhydramnios. Chromosome analysis was normal $(46, \mathrm{XX})$. Intrauterine fetal death (IUFD) of the female fetus (Fig. 1, 1.3) was diagnosed at gestational week $31^{+3}$. Clinical examination of the deceased fetus after birth at week $32^{+0}$ showed hydrops fetalis and normal measurements (length $40 \mathrm{~cm}$ (21 percentile, $Z=-0.79$ ), weight of $1185 \mathrm{~g}$ ( 6 percentile, $Z=-1.54$ ), head circumference of $29 \mathrm{~cm}$ (34 percentile, $Z=-1.69)$ ). The fetus had small deepset ears, a flat facial profile, and normal hands and feet.

We performed exome analysis on all three affected siblings.

\section{Family 2}

The boy (Fig. 1, 2.1) was the second child of consanguineous parents with an uneventful family history. During the complicated pregnancy, polyhydramnios was diagnosed at 31st week and a right ventricle hypertrophy in the course of the 33rd week. Birth was carried out per cesarean section at gestational week $37^{+1}$ (APGAR 01/05/
07) and the birth weight was $2770 \mathrm{~g}$ (21 percentile, $Z=$ -0.82 ). The child was intubated immediately after birth due to suspected heart disease. Thereafter, cardiac arrhythmias with persistent ventricular tachycardia occurred and turned out to be refractory to therapy. Cardiopulmonary resuscitation was performed three times without success after the occurrence of ventricular tachycardia and bradycardia leading to asystole. Peripheral Venous Arterial ECMO was initiated because of insufficient circulation. Due to persistent arrhythmias and severe right ventricle insufficiency, all life-saving measures were discontinued. As a consequence of broad-complex ventricular tachycardia, the child died at the age of 5 days.

Physical examination revealed mild dysmorphic features, a cystic neck hygroma and a hypoplastic scrotum, dystrophic nails, and small ribs on X-ray. The neuropathological investigation of the right quadriceps femoris showed ageappropriate skeletal muscles and no pathological findings.

\section{Genetic results}

In family 1, ES revealed the homozygous frameshift variant NM_022902.4(SLC30A5):c.832_836del p.(Ile278Phefs*33) in 


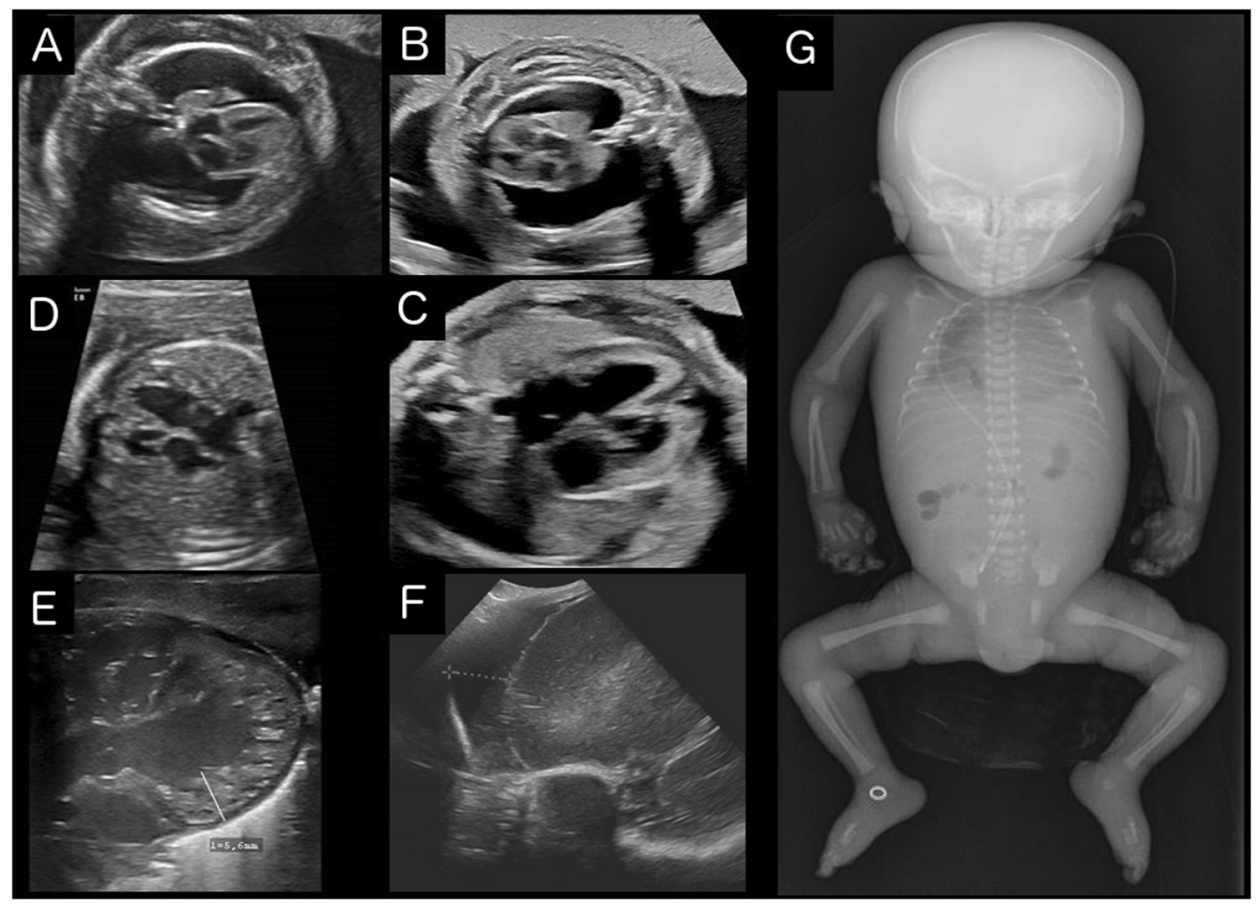

Fig. 2 Imaging findings of the affected individuals. Prenatal ultrasound scans at the level of four-chamber view of individuals of family 1 (A: Voluson S8, AB2-7 convex abdominal ultrasound transducer 2-8 MHz; B: Voluson E8, RAB 6-D convex abdominal transducer 2-8 MHz; C, D: Philips EPIQ Elite, V 2-7 convex abdominal ultrasound transducer 2-9 MHz): fetus 1.1 at 28 weeks of gestation $(\mathbf{A})$ and fetus 1.3 at 31 weeks of gestation (B) showing edematous skin and lungs maximally compressed by massive pleural effusions, polyhydramnios. Prenatal myocardial hypertrophy in fetus 1.2 at 25 weeks

all three fetuses. Both parents are heterozygous. In family two, ES affirmed the homozygous frameshift variant NM_022902.4 (SLC30A5):c.1981_1982del p.(His661Tyrfs*10) in the affected child. Both parents are heterozygous.

Both detected variants are absent from publicly available databases, including gnomAD [15], and also from our inhouse databases in Leipzig and Zürich. We assume that both frameshifts probably result in a full LoF of the protein. In gnomAD, no homozygous $\mathrm{LoF}$ variants can be found in this gene.

\section{Discussion}

Here we describe four individuals in two unrelated consanguineous families with lethal cardiomyopathy, arrhythmia, and hydrops fetalis/cystic hygroma in whom we identified homozygous variants in SLC30A5.

We identified the homozygous variant NM_022902.4: c.832_836del p.(Ile278Phefs*33) in all three affected individuals of the first family, while the affected child of the second family carried the homozygous variant of gestation (C) and in fetus 1.3 at 28 weeks of gestation (D). Postnatal ultrasound scans of individual 1.2 (Zonare ZS3, Mindray, USA): E spongy left ventricular myocardium (nonstandard plane nonstandard with $20 \mathrm{MHz}$ linear transducer), $\mathbf{F}$ frontal hygroma in parasagittal view (blue crosses mark a distance of $1.2 \mathrm{~cm}, 7,5 \mathrm{MHz}$ curved array transducer). G Postmortem babygram of individual 1.2 (born $31^{+2}$, deceased on the 4th day of life) showing thickened soft tissue and pleural effusion on the right side, normal skeletal findings (color figure online).

NM_022902.4:c.1981_1982del p.(His661Tyrfs*10). We assume that the position of the variants in or outside of any of the protein domains is irrelevant as both variants lead to frameshifts and are predicted to result in a LoF due to nonsense mediated decay. The minor allele frequency of all SLC30A5 LoF variants in gnomAD is 1:4330 with no reported homozygous LoF variants. Even assuming that the first identified LoF in this study is not relevant to the phenotype, the probability of identifying a second homozygous LoF in SLC30A5 in a cohort of 50,000 cases (there are 44,000 entries in GeneMatcher) by chance is 0.0027 , making a coincidental event highly improbable.

In addition, all four affected patients show a strong phenotypic similarity including perinatal lethality and either fetal hydrops or cystic hygroma. Apart from the first affected child (1.1), who did not receive echocardiography, all other individuals had cardiomyopathy. Both children that were born alive and later received clinical examination (1.2 and 2.1) were diagnosed with arrhythmia. The other two children died of an unknown cause; arrhythmia would fit into the clinical course. We therefore assume these variants to be causative for the clinical features. 
SLC30A5 encodes for ZnT-5, a zinc transporter. Zinc is the most abundant trace element in human cells [17] and about $10 \%$ of all eukaryotic proteins need zinc to fulfill their cellular activity [18]. This makes zinc essential for a broad spectrum of cellular functions [19], e.g., transcription, ATP production and mitochondrial apoptogenesis [20], activation of enzymes in the early secretory pathway [21], microtubule formation [22], and intracellular signaling [23]. The intracellular zinc homeostasis is hence kept within narrow limits by a battery of zinc transporters [24]; mainly 14 zinc importers (SLC39 family, ZIP channels) and $10 \mathrm{Zn}$ exporters (SLC30 family, ZnT channels). Of the $10 \mathrm{ZnTs}$, ZnT-10 (SLC30A10, OMIM *611146, OMIM \#613280, [25]) is associated with the autosomal recessive hypermanganesemia with dystonia 1, while ZnT-2 (SLC30A2, OMIM *609617, OMIM \#608118, [26]), ZnT-5 (sLC30A5, оMIM *607819, [27]), and ZnT-6 (sLC30A5, оMIM *611148, [27]) have been linked to a reduced amount of zinc in mother milk leading to dermal symptoms in the infant. Of the 14 ZIPs, four are associated with autosomal recessive disorders including a broad spectrum of phenotypes: acrodermatitis enteropathica (ZIP4, SLC39A4, OMIM *607059, OMIM \#201100, [28]), congenital disorder of glycosylation type IIn with intellectual disability and short stature (ZIP8, SLC39A8, OMIM *607059 \#616721, [29]), Ehlers-Danlos syndrome of spondyloplastic type 3 (ZIP13, SLC39A13, OMIM *608735 \#612350, [30]), hypermanganesemia with dystonia 2 (ZIP14, SLC39A14, OMIM *608736 \#617013, [31]), and one autosomal dominant phenotype of severe myopia (ZIP5, SLC39A5, OMIM *608730 \#615946, [32]). In addition, several studies have shown variable clinical presentation of loss of zinc transporters in mice [33, 34]. The broad spectrum of both clinical presentations and pathomechanisms is in line with the large number of cellular functions of zinc. The limitation of symptoms to individual organs could be explained by specific expressions of cellular functions through different zinc transporters. ZIP4, for example, is associated with acrodermatitis enteropathica and mostly expressed in the digestive tract.

SLC30A5 encodes ZnT-5, which is localized at membranes of endoplasmic reticulum and Golgi apparatus. It forms heterodimers with $\mathrm{ZnT}-6$ [21]. Its function is the influx of $\mathrm{Zn}^{2+}$ ions into the lumen of the cell organelles. With respect to the various functions of zinc, it is conceivable that a disturbed zinc homeostasis due to a total LoF of $\mathrm{ZnT}-5$ could have remarkable consequences.

Inoue et al. [34] have examined $\mathrm{ZnT}-5$, the $\mathrm{Zn}^{2+}$ channel encoded by SLC3OA5 in a knockout mouse model. The mice showed reduced body growth and reduced bone density. About $60 \%$ of the mice died due to bradyarrhythmia. As both knockout mice and affected individuals had cardiac arrhythmia, we see an analogy of the phenotypic spectrum. We consider the results of the study of Inoue et al. as a further line of evidence regarding the association between bi-allelic LoF in SLC3OA5 and cardiomyopathy. We also suggest that the pathomechanism is possibly a disturbed cardiac conduction. This is further supported by the results of Lin et al. [33], who showed that SLC39A8-null mice exhibit cardiomyopathic phenotypes of the non-compaction type, which was also present in at least two of the four affected patients. ZIP8 (SLC39A8) is one of several $\mathrm{Zn}^{2+}$ transporters that are responsible for the influx of $\mathrm{Zn}^{2+}$ into the cell. This is a requirement for the subsequent transport of the ions into the endoplasmic reticulum by $\mathrm{ZnT}-5$. It seems therefore plausible that a LoF of ZnT-5 can lead to a similar phenotype as the loss of ZIP8. However, the specific pathomechanism remains unknown up until now and needs to be investigated in future studies. Additional families with affected children will help to further statistically substantiate the suspected association.

Interestingly, in all studied cases hydrops fetalis/cystic hygroma occurred late in pregnancy, with a diagnosis being made as late as 20 weeks of gestation or even at birth, albeit regular sonographic controls. McCoy et al. [35] even state that a hydrops fetalis is more likely to be caused by cardiothoracic abnormalities the later in the pregnancy the diagnosis was made. Cystic hygroma normally develops by the end of the 6 th week of gestation but was not found for individual 2.1 on sonographic screenings before birth.

In conclusion, here we describe four individuals from two families with perinatal lethal cardiomyopathy, all of which have bi-allelic LoF variants in the zinc transporter SLC30A5. For the first time, we are able to link bi-allelic LoF variants in this gene with a human disease. Although the pathomechanisms are not yet understood, they seem to fit in the spectrum of zinc transporters. Further analyses are needed to investigate these mechanisms.

Funding Open Access funding enabled and organized by Projekt DEAL.

\section{Compliance with ethical standards}

Conflict of interest The authors declare that they have no conflict of interest.

Ethical approval Patients were enrolled and sampled according to standard local practice in approved human subjects' protocols as part of routine clinical care at the respective institutes. The project was approved by the ethic committee of the University of Leipzig, Germany (224/16-ek and 402/16-ek) and was conducted in concordance to the declaration of Helsinki.

Informed consent Written informed consent of all examined individuals or their legal representatives for genetic testing and the publication of findings was obtained after advice and information about the risks and benefits of the study. 
Publisher's note Springer Nature remains neutral with regard to jurisdictional claims in published maps and institutional affiliations.

Open Access This article is licensed under a Creative Commons Attribution 4.0 International License, which permits use, sharing, adaptation, distribution and reproduction in any medium or format, as long as you give appropriate credit to the original author(s) and the source, provide a link to the Creative Commons license, and indicate if changes were made. The images or other third party material in this article are included in the article's Creative Commons license, unless indicated otherwise in a credit line to the material. If material is not included in the article's Creative Commons license and your intended use is not permitted by statutory regulation or exceeds the permitted use, you will need to obtain permission directly from the copyright holder. To view a copy of this license, visit http://creativecommons. org/licenses/by/4.0/.

\section{References}

1. Oster RT, Toth EL, Retrospective A. Analysis of stillbirth epidemiology and risk factors among First Nations and non-First Nations Pregnancies in Alberta from 2000 to 2009. J Obstet Gynaecol Can. 2015;37:117-21.

2. Blencowe H, Cousens S, Jassir FB, Say L, Chou D, Mathers C, et al. National, regional, and worldwide estimates of stillbirth rates in 2015, with trends from 2000: a systematic analysis. Lacent Glob Health. 2016;4:e98-108.

3. McClure EM, Nalubamba-Phiri M, Goldenberg RL. Stillbirth in developing countries. Int J Gynaecol Obstet. 2006;94:82-90.

4. Aminu M, Unkels R, Mdegela M, Utz B, Adaji S, van den Broek $\mathrm{N}$. Causes of and factors associated with stillbirth in low- and middle-income countries: a systematic literature review. BJOG. 2014;121 Suppl 4:141-53.

5. McPherson E. Hydrops fetalis in a cohort of 3,137 stillbirths and second trimester miscarriages. Am J Med Genet Part A. 2019; 179:2338-42.

6. Mardy AH, Chetty SP, Norton ME, Sparks TN. A system-based approach to the genetic etiologies of non-immune hydrops fetalis. Prenat Diagn. 2019;39:732-50.

7. Santo S, Mansour S, Thilaganathan B, Homfray T, Papageorghiou A, Calvert S, et al. Prenatal diagnosis of non-immune hydrops fetalis: what do we tell the parents? Prenat Diagn. 2011;31:186-95.

8. Bellini C, Donarini G, Paladini D, Calevo MG, Bellini T, Ramenghi LA, et al. Etiology of non-immune hydrops fetalis: an update. Am J Med Genet A. 2015;167A:1082-8.

9. Sparks TN, Thao K, Lianoglou BR, Boe NM, Bruce KG, Datkhaeva I, et al. Nonimmune hydrops fetalis: identifying the underlying genetic etiology. Genet Med. 2019;21:1339-44.

10. Lord J, McMullan DJ, Eberhardt RY, Rinck G, Hamilton SJ, Quinlan-Jones E, et al. Prenatal exome sequencing analysis in fetal structural anomalies detected by ultrasonography (PAGE): a cohort study. Lancet. 2019;393:747-57.

11. Petrovski S, Aggarwal V, Giordano JL, Stosic M, Wou K, Bier L, et al. Whole-exome sequencing in the evaluation of fetal structural anomalies: a prospective cohort study. Lancet. 2019;393:758-67.

12. Sobreira N, Schiettecatte F, Valle D, Hamosh A. GeneMatcher: a matching tool for connecting investigators with an interest in the same gene. Hum Mutat. 2015;36:928-30.

13. Landrum MJ, Lee JM, Benson M, Brown GR, Chao C, Chitipiralla $\mathrm{S}$, et al. ClinVar: improving access to variant interpretations and supporting evidence. Nucleic Acids Res. 2018;46:D1062-7.

14. Stenson PD, Mort M, Ball EV, Evans K, Hayden M, Heywood S, et al. The Human Gene Mutation Database: towards a comprehensive repository of inherited mutation data for medical research, genetic diagnosis and next-generation sequencing studies. Hum Genet. 2017;136:665-77.

15. Karczewski KJ, Francioli LC, Tiao G, Cummings BB, Alföldi J, Wang Q, et al. The mutational constraint spectrum quantified from variation in 141,456 humans. Nature. 2020;581:434-43.

16. Voigt M, Fusch C, Olbertz D, Hartmann K, Rochow N, Renken C, et al. Analyse des Neugeborenenkollektivs der Bundesrepublik Deutschland. Geburtsh Frauenheilk. 2006;66:956-70.

17. Vallee BL, Falchuk KH. The biochemical basis of zinc physiology. Physiological Rev. 1993;73:79-118.

18. Kambe T, Matsunaga M, Takeda T-A. Understanding the contribution of zinc transporters in the function of the early secretory pathway. Int J Mol Sci. 2017;18:2179.

19. Hennigar SR, Kelleher SL. Zinc networks: the cell-specific compartmentalization of zinc for specialized functions. Biol Chem. 2012;393:565-78.

20. Costello LC, Franklin RB, Feng P. Mitochondrial function, zinc, and intermediary metabolism relationships in normal prostate and prostate cancer. Mitochondrion. 2005;5:143-53.

21. Fukunaka A, Suzuki T, Kurokawa Y, Yamazaki T, Fujiwara N, Ishihara $\mathrm{K}$, et al. Demonstration and characterization of the heterodimerization of ZnT5 and ZnT6 in the early secretory pathway. J Biol Chem. 2009;284:30798-806.

22. Oteiza PI, Hurley LS, Lönnerdal B, Keen CL. Effects of marginal zinc deficiency on microtubule polymerization in the developing rat brain. Biol Trace Elem Res. 1990;24:13-23.

23. Yamasaki S, Sakata-Sogawa K, Hasegawa A, Suzuki T, Kabu K, Sato E, et al. Zinc is a novel intracellular second messenger. J Cell Biol. 2007;177:637-45.

24. Sekler I, Sensi SL, Hershfinkel M, Silverman WF. Mechanism and regulation of cellular zinc transport. Mol Med. 2007;13:337-43.

25. Tuschl K, Clayton PT, Gospe SM, Gulab S, Ibrahim S, Singhi P, et al. Syndrome of hepatic cirrhosis, dystonia, polycythemia, and hypermanganesemia caused by mutations in SLC30A10, a manganese transporter in man. Am J Hum Genet. 2012;90:457-66.

26. Chowanadisai W, Lönnerdal B, Kelleher SL. Identification of a mutation in SLC30A2 (ZnT-2) in women with low milk zinc concentration that results in transient neonatal zinc deficiency. J Biol Chem. 2006;281:39699-707.

27. Kumar L, Michalczyk A, McKay J, Ford D, Kambe T, Hudek L, et al. Altered expression of two zinc transporters, SLC30A5 and SLC30A6, underlies a mammary gland disorder of reduced zinc secretion into milk. Genes Nutr. 2015;10:487.

28. Küry S, Dréno B, Bézieau S, Giraudet S, Kharfi M, Kamoun R, et al. Identification of SLC39A4, a gene involved in acrodermatitis enteropathica. Nat Genet. 2002;31:239-40.

29. Boycott KM, Beaulieu CL, Kernohan KD, Gebril OH, Mhanni A, Chudley AE, et al. Autosomal-recessive intellectual disability with cerebellar atrophy syndrome caused by mutation of the manganese and zinc transporter gene SLC39A8. Am J Hum Genet. 2015;97: 886-93.

30. Giunta C, Elçioglu NH, Albrecht B, Eich G, Chambaz C, Janecke AR, et al. Spondylocheiro dysplastic form of the Ehlers-Danlos syndrome-an autosomal-recessive entity caused by mutations in the zinc transporter gene SLC39A13. Am J Hum Genet. 2008;82: 1290-305.

31. Tuschl K, Meyer E, Valdivia LE, Zhao N, Dadswell C, Abdul-Sada A, et al. Mutations in SLC39A14 disrupt manganese homeostasis and cause childhood-onset parkinsonism-dystonia. Nat Commun. 2016;7:11601.

32. Guo H, Jin X, Zhu T, Wang T, Tong P, Tian L, et al. SLC39A5 mutations interfering with the BMP/TGF- $\beta$ pathway in nonsyndromic high myopia. J Med Genet. 2014;51:518-25.

33. Lin W, Li D, Cheng L, Li L, Liu F, Hand NJ, et al. Zinc transporter Slc39a8 is essential for cardiac ventricular compaction. J Clin Investig. 2018;128:826-33. 
34. Inoue $\mathrm{K}$, Matsuda $\mathrm{K}$, Itoh M, Kawaguchi H, Tomoike H, Aoyagi $\mathrm{T}$, et al. Osteopenia and male-specific sudden cardiac death in mice lacking a zinc transporter gene, Znt5. Hum Mol Genet. 2002;11:1775-84.
35. McCoy MC, Katz VL, Gould N, Kuller JA. Non-immune hydrops after 20 weeks' gestation: review of 10 years' experience with suggestions for management. Obstet Gynecol. $1995 ; 85: 578-82$. 